\title{
Features Affecting Improved Housing Managerial Services of Slum Rehabilitation Scheme (SRS) Apartments in Mumbai, India
}

\author{
Sayeda Saika Binte ALAM*, Mihoko MATSUYUKI**
}

\begin{abstract}
:
This article discusses and observes three case studies on cooperative housing societies of SRS apartments located in (1) Dharavi, (2) Lower Parel, and (3) Chandivali in Mumbai. Mumbai's Slum Rehabilitation Scheme (SRS) apartments need quality building maintenance services to achieve dwellers' high satisfaction. Therefore, in this research, current managerial services and the way to improve management of SRS apartments are discussed. The discussion within the article provides three analytical frameworks of three targeted cooperative societies, guided by recent management activity in consideration of society members' responses. The research utilizes building maintenance services instructed in Maharashtra housing maintenance regulations and an official report published in 2012 to discuss the necessary features that should remain in managerial services. The research found that monitoring by the authority was absent in the three case studies on cooperative societies, resulting in regulatory violence and financial mismanagement in the old SRS apartments. A lack of supervision after apartment allotment by the Slum Rehabilitation Authority (SRA) was observable during discussions and visits. Moreover, no regulation was proposed or added by the SRA to improve the current scenario of management in old SRS apartments. The research revealed that monitoring and supervision after allotment improves the condition of managerial services of SRS apartments. Women's participation affects and improves overall management and maintenance services in SRS apartments without a high maintenance cost.
\end{abstract}

Keywords: Slum Rehabilitation Scheme (SRS), Apartment Managerial Services, Housing Cooperative Society

\section{Introduction}

The United Nations Human Settlement Program, UN-Habitat, has indicated an intense state of urban slums and provided the rational way to overcome this problem is mainly related to land tenure lasting several years (Nijman; 2008, Davis; 2006, Neuwirth; 2004). ${ }^{1) 2), 3)}$ The Participatory Slum Upgrading Programme, the "Slum Almanac 2015-2016," mentioned the increasing of slum populations, especially in cities of developing countries, with a total of 881 million slum inhabitants worldwide (UN Habitat; 2015-16). ${ }^{4)}$ The swelling of slums is starting to overlap into urban areas, especially in development plans. Thus, the World Bank, along with the central and municipal governments of developing nations, have initiated many policies to reduce the growing phenomenon of urban slums. Geurts and Joldersma ${ }^{5)}$ (2001) discussed development through policy analysis and practices which demonstrates a shift from a central, analytical, and scientific

*Housing \& Building Research Institute (HBRI), Bangladesh, saika15alam@gmail.com

** Institute of Urban Innovation, Yokohama National University, mihoko@ynu.ac.jp 
approach to a more multi-central, interactive stakeholder approach. Recent policy agendas of slum rehabilitation have been reshaped in a way where the central governments transfer the responsibility to local governments, NGOs, and the market (Nijman; 2008, Restrepo; 2009, Jagdale; 2014). ${ }^{1), 6), 7)}$ In these policies, community participation is a crucial element in devising solutions to major urban issues (Agbola; 1994) ${ }^{8)}$ Therefore, involving the local slum communities seems to be a remedy in handling challenges to the policy that confirms a positive impression of managing slum growth. This article discusses the process of managerial services of rehabilitated apartments by the slum cooperative societies in Mumbai. It also debates the recent actions of managerial services and some possibilities. The policy commonly known as the Slum Rehabilitation Scheme (SRS) and its building construction and apartment management process are executed by the slum cooperative society. The scheme derives from free market ideology, which ensures success. Mumbai is the second most influential city in India in terms of economy, and it depends greatly on the freemarket economy. So, if a market does not exist, it needs to be created (Mukhija; 2001, Nijman; 2008). ${ }^{9), 1)}$

Free housing to slum dwellers has received numerous criticisms, both positive and negative, about deploying repeated modifications in construction criteria. Since the scheme derives from the market and local builders are the executors of SRS projects, some researchers have predicted that builders concentrate more on their profits instead of considering slum dwellers' requirements (Das; 2003, Ronita, Sayantani, Arnab, and Nagendra; 2015). ${ }^{10), 11)}$ Furthermore, the scheme has been noticed by several researchers because of its independent governmental body, the Slum Rehabilitation Authority (SRA) and its concept of freemarket ideology through slum land privatization. Mumbai suffers from a land crisis because the city has continuously been expanding (Zope et al. 2015, Nallathiga; 2005), ${ }^{12), 13)}$ so further extension would be difficult. Due to this, land is in high demand to local builders. Since the SRS offers a slum-occupied area with reasonably low prices to local builders to develop within a legal procedure, so, private developing companies show a high interest. The private builder's demand enhances the scheme; therefore, the scheme continues its progress to rehabilitate the slum areas. Indeed, the adaptation of many acts, policies, and actions to control the growth rate of slums by providing tenure security, but many researchers have criticized this approach and recommend modifications (Banerjee; 2004, Neelima Risbud; 2003, Ronita, Sayantani, Arnab, and Nagendra; 2015, Jagdale; 2015). ${ }^{14), 15), 11), 7)}$ Some researchers argued about the necessity of modifications of the physical conditions of the SRS apartments (Banerjee; 2004, Das; 2003, Mukhija; 2001). ${ }^{14), 10), 9)}$ Unquestionably, the physical condition affects dwellers' satisfaction with living situations, but the dwellers' living satisfaction mainly depends on the quality of maintenance services provided by the cooperative housing society (Alam, Matsuyuki; 2017) ${ }^{16)}$ Therefore, the maintenance services of the apartment need to be improved accordingly. Consequently, determining the necessary features and actions of management systems in SRS apartments is essential. However, there has not been any research revealing the necessary features to be included in the managerial action to improve the overall management of SRS apartments until now.

This paper mainly focuses on how the features of managerial services affect outcomes and how to improve SRS apartments' maintenance services. There is typically a standard for management and maintenance regulation in all housing societies within the peripheral boundary of Maharashtra. 
Slum Rehabilitation Scheme apartments also follow these rules. The present research intended to examine the following questions.

Research Question-1: What are the main features for SRS apartment's managerial action? ${ }^{1}$

Research Question-2: What would be the necessary mechanism to improve the overall maintenance system of all SRS apartments?

The present article focuses on interviews conducted in January 2018 with the secretaries of cooperative societies at the three case study SRS apartments located in three different areas in Mumbai. The outline of the interviewed cooperative societies is summarized in Table 1.

Table 1. Outline of Interviewed Cooperative Societies of SRS Apartments

\begin{tabular}{|lrrr|}
\hline Cooperative Societies & $\begin{array}{r}\text { Location of SRS } \\
\text { Apartment }\end{array}$ & $\begin{array}{r}\text { Year Society was } \\
\text { Established }\end{array}$ & $\begin{array}{r}\text { Number of Households } \\
\text { Under the Society } \\
171 \text { Households }\end{array}$ \\
\hline $\begin{array}{l}\text { Muslim Nagar Nabi Nagar } \\
\text { Cooperative Society }\end{array}$ & Dharavi, Mumbai & 1995 & 254 Households \\
$\begin{array}{l}\text { Gomata Janata SRA } \\
\text { Cooperative Society } \\
\text { Sivneri Society of SRA }\end{array}$ & $\begin{array}{r}\text { Lower Parel, } \\
\text { Mumbai }\end{array}$ & 2006 & \\
\hline & $\begin{array}{r}\text { Chandivali, } \\
\text { Mumbai }\end{array}$ & 2006 & 48 Households \\
\hline
\end{tabular}

Table 1. Outline of Interviewed Cooperative Societies of SRS Apartments

The discussion of the research has been based on the interviews of the secretaries in the three case study cooperative societies of SRS apartments. The study also consults literature on housing maintenance and "Model Bye-Laws of Cooperative Housing Society" as per the 97th Constitutional Amendment and Maharashtra Cooperative Societies (Amendment; 2013) ${ }^{17}$. The article also analyzes a government report: Management and Maintenance of Tenements: Final Detail Report based on "Support to National Policies for Urban Poverty Reduction" (SNPUPR; $2013)^{18)}$ for the Strengthening National Resource Center (NRC) of India. The information from these sources, along with the responses from the interviews with the secretaries of the cooperative society have been represented in three analytical frameworks. The analytical framework shows the current conditions of managerial services of three case study SRS apartments and introduces basic managerial features and the possibilities of their contribution to building maintenance services.

The structure of the paper is as follows: the study initially provides a brief explanation of Mumbai's Slum Rehabilitation Scheme (SRS) and then discusses the level of dwellers' satisfaction with maintenance services of their apartment. The empirical part of the research

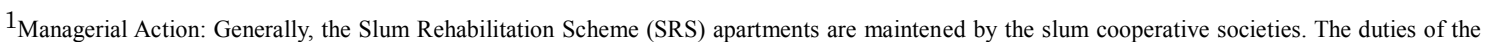
apartment maintenance are appointing staff for cleaning, handling monthly common space electric and other bill, taxation of the property. The society also collects monthly maintenance charges from the dwellers and arranges general meetings and Annual General Meeting (AGM) with dwellers to improve maintenance service (SRA; 2018). In this article, these duties are considered as managerial actions.
} 
discusses the mandatory features of management services and their necessity to remain in the housing societies. Next, the study presents three analytical frameworks with a brief explanation of the recent features of the management and maintenance services of three SRS apartments considering the replies of the secretaries from the cooperative societies. Then, a discussion on a mechanism to improve the managerial services of the case study SRS apartments will be introduced. The last section of the article is the conclusion with some recommendations in improvement.

\section{Mumbai's Slum Rehabilitation Scheme (SRS)}

According to the Constitution of India, housing supplies are the government's responsibility, which includes housing, lands, urban development, and infrastructure provisions of the city (Ronita et al. 2015). ${ }^{11)}$ However, access to affordable housing depends on income, which often forces low-income groups to reside in slum and squatter settlements, sometimes without the legal right. In Mumbai, housing problems - especially in the case of affordability - have been detected over the last 150 years, whereas the number of affordable house provisions by the state remains quite low (Nijman; 2008). ${ }^{1)}$ The government has taken several measures and provided policies and acts related to efforts to reduce the strain in housing availability, especially after 1985 (Mahadevia; 2014, Jagdale; 2014). ${ }^{19,7)}$ Slum rehabilitation started when the government awarded a grant for legal housing to slum dwellers in Dharavi in 1985 (Mukhija; 2001). ${ }^{9}$ The actions were under the Prime Minister Grant Project (PMGP), wherein the process involved demolishing a slum, building legal housing on the original site, and giving a low-interest loan facility to the dwellers. The policy needed to be revised, as the number of houses provided from the grant was limited and dwellers' contributions including loan services were insufficient. Recognizing the obstacles, revisions were carried out under a new name the Slum Redevelopment Scheme (SRD) in 1991, which stated that dwellers were not required to contribute, because the government encouraged a free market ideology. However, the scheme faced several administrative actions which took time, and less productivity encouraged another revision. Then, the Slum Rehabilitation Scheme (SRS) was formed in 1995 while the governmental authority, the Slum Rehabilitation Authority (SRA), served all administrative actions under one roof (Jagdale; 2015, Mukhija; 2001 and Ronita et al.; 2015). ${ }^{7,9), 11)}$ Therefore, SRS can be defined as a revised policy originating from years of learning through action and evolving toward success. The current article focuses on the scheme for its success story as well as its criticism. However, SRS is not the only slum rehabilitation policy in India that has received disapproval by local researchers; instead, it is a sequential process which forces policymakers to improve the policy periodically.

\section{2-1 SRS Apartment Dwellers' Satisfaction with its Housing Managerial Services}

As stated above, SRS apartment dwellers' degree of living satisfaction depends on their level of maintenance satisfaction. However, the degree of maintenance service satisfaction is not equal in the three case studies of SRS apartments (Alam and Matsuyuki; 2018). ${ }^{16)}$ Particularly, the dwellers who live in old apartments are unsatisfied with their living conditions and with their maintenance service. Among the three case study SRS projects, Dharavi SRS is the oldest project. 
Figure 1: SRS Apartment Dwellers' Satisfaction on Management Service in Three Case Study Cooperative Societies at Mumbai

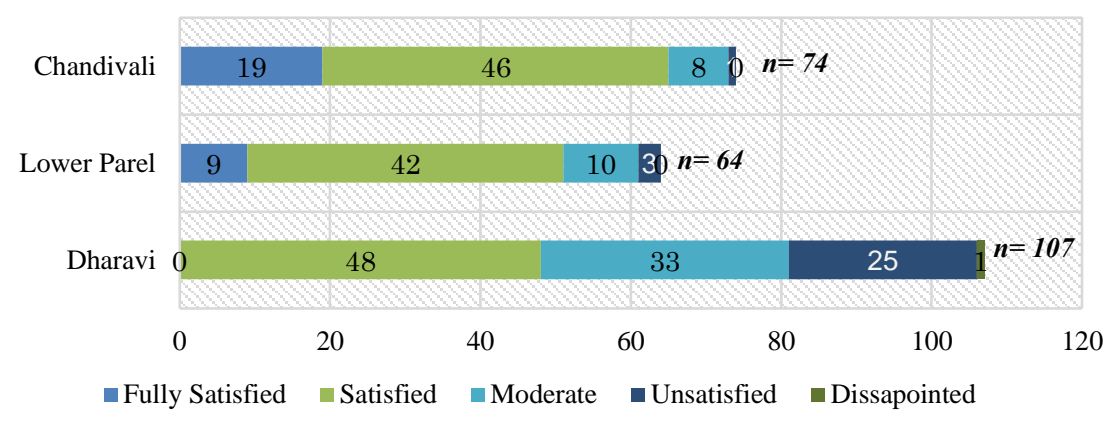

Figure 1: SRS Apartment Dwellers' Satisfaction on Management Service in the Three Case Study Cooperative Societies at Mumbai

Data Source: Alam and Matsuyuki; 2018

Figure 1 represents the maintenance service satisfaction rate, where no dwellers in SRS apartments located at Dharavi are fully satisfied with their maintenance service. Only 48 dwellers among 107 are satisfied. In the SRS project at Lower Parel, 51 out of 64 dwellers are satisfied, whereas only 9 are fully satisfied with the maintenance services. In the case of Chandivali SRS apartments, 46 out of 74 are satisfied and 19 are fully satisfied with the maintenance services. The researches found that the dwellers who lived in the old SRS apartments were unsatisfied with the management and maintenance services. For this reason, the research intended to identify the necessary features of managerial services in SRS apartments.

\section{Necessary Features for Management and Maintenance in SRS Apartments}

Cooperative Housing Societies (CHS) of SRS apartments follow standard regulations that all housing societies in the Maharashtra state adhere to. According to the housing management rule of Maharashtra and recommendation by some literature, at least four mandatory features should be present in the managerial services in every SRS apartment. Furthermore, during the interview with the secretaries of the cooperative societies of SRS apartments, the study observed features such as: (1) Financial Management, (2) Institutional Mechanism, and (3) General Body Meeting with Dwellers, are commonly available in the management services. However, another feature, (4) Monitoring by the Authority, is also recommended in the literature; therefore, this feature is included in the proposed method in the study.

The presence of these four features in the cooperative societies of SRS apartments would improve the overall managerial services. The four features of management services of SRS apartments are explained below.

\section{3-1 Financial Management}

The cooperative societies of SRS apartments in Mumbai should offer two types of financial 
management services: a) dwellers assets maintenance ${ }^{2}$ and b) day-to-day maintenance services ${ }^{3}$.

\section{(a) Dwellers' Asset Maintenance}

All eligible owners of SRS apartments are now receiving 20,000 rupees/household (at first, the amount was 10,000 rupees/household) from private builders as a maintenance subsidy, along with their flat/room. The dwellers generally handed the amount to the society for deposing the amount in a bank. Then, the society started to receive a 7\% yearly interest rate from the bank. The society uses the earned interest for the common spaces ${ }^{4}$ including the electrical, water, and sanitation bills and taxation of the building. For example, there are 254 households in SRS apartments at Lower Parel. Therefore, the total amount of dwellers' assets is 5.08 million rupees, which they hand to the cooperative society. The cooperative society receives 29,633 rupees per month as an interest from the bank, and they use this amount for common space maintenance and building taxation (SRA; 2018). ${ }^{20)}$

\section{(b) Day-to-day Maintenance}

Unlike all apartment dwellers in Mumbai, those in the SRS apartment also need to pay maintenance charges to the cooperative society every month. According to bylaw No. 69(a), a "Committee shall fix a rate in respect of every household in the society as a charge for maintenance fee/month" (hereafter referred to as the "2013 Regulations"). The society allocates the collected funds to the salaries of the maintenance staff such as cleaners, sweepers, and guards. Coase $^{21)}(1960)$ argued that both external and internal divisions of the institutions cannot provide quality service with zero cost. The government report under SNPUPR ${ }^{18)}$ (2013) mentioned that the regular monthly charge to the dwellers should be mandatory despite participatory governance. Therefore, all dwellers should pay the maintenance charge to the cooperative societies of SRS apartments without failure to execute the maintenance services. The research considers the feature "Financial Maintenance" in the analytical frameworks because it serves as one of the most important managerial actions handled by the cooperative housing societies of SRS apartments.

\section{3-2 Institutional Mechanism}

International Cooperative Alliance ${ }^{22}$ (ICA, 1996) defines a cooperative as an autonomous association of members to meet economic, social, and cultural needs through a jointly owned and democratically controlled enterprise. Running a successful cooperative society requires a certain number of members and staff. The cooperative societies of SRS apartments consist of members and staff; here, the secretary is the key decision maker and conducts the primary managerial actions, such as handling the dwellers' asset and day-to-day maintenance. A cooperative body is

\footnotetext{
2 Dweller's Asset Maintenance: Developers subsidize an amount as a maintenance subsidy to all eligible households (the households that have the evidence of stay in the slum area following the required years by SRA for eligibility). Eligible slum dwellers are given 20,000 rupees per household by the developing companies (SRA; 2018). These amounts are reserved in the bank for long-term maintenance cost, and the monthly interest (@7\% yearly) of this amount is used for the common space electric bill, water and sanitation bill, and taxation of the property (SRA; 2018).

3 Day to Day Maintenance: It is an everyday maintenance service by the staff which are monitored by the secretary. The service, such as cleaning the shared space, door-to-door garbage collection, cleaning surrounding area of the building, maintaining water pump and common electric meters, entrance security and so on, are written in the ordinance 2013 and the rule-book for the maintenance services that need to supplied by SRA.

${ }^{4}$ Common Space: All dwellers of SRS apartments use some common places such as corridor, lobby, and staircase. These places are cleaned by the housing societies of the building. Furthermore, the electric billing and maintenance of elevator are also the responsibility of the cooperative societies.
} 
an autonomous and independent organization where the members control the decision-making process; however, the process and the maintenance actions should consider the regulations (G. Sukumar; 2001). ${ }^{23)}$ According to Regulation 156(a), the registered committee shall, with the approval of the General Body, take necessary steps for Conveyance/Deemed Conveyance of the buildings in favor of the society (2013 Regulations). Therefore, this study considered whether the institutional bodies of the cooperative societies have the required number of members and staff as per the regulation. All SRS apartments follow the manual distributed by SRA, which proposes a specific number of individuals for managerial services; these members should hold an election every three to five years (SRA; 2018). ${ }^{20)}$

\section{3-3 Society General Meeting with Dwellers}

The society's "General Meeting with Dwellers" is one of the necessary actions indicated in housing regulations, as the meeting with the dwellers is the only source to discuss and negotiate the managerial actions with cooperative members and household members. According to the regulation, members should call for a general body meeting with the dwellers once every three months, however, after the first meeting, the society members will decide the date and topic of the next meeting (Amendment; 2013) ${ }^{17}$ ). Furthermore, the SRS apartment management regulations provide the flexibility to call for a meeting during an emergency and societies could also arrange regular monthly meetings (SRA; 2018). ${ }^{20)}$ Section 129(1) of the regulation booklet mentions the committee shall meet as often as necessary but at least once a month. So, the committee members of the societies should sit for a meeting at least once in month with household members as per the regulation. The first society general meeting should be called by the chief promoter or the representatives mentioned in Rule-59; 2013 (Amendment) ${ }^{17)}$. As per the regulation, societies should call for the first meeting on the third month of the property (room/flat) allotment. The necessary actions discussed in the meeting are to resolve emergency issues, announce benefits and productions, declare the appointment or termination of staff, and deliberate on the recent condition of the dwellers' assets and fixing the monthly maintenance fee (Amendment; 2013) ${ }^{17)}$.

Consistent with the law, societies of SRS apartments should call for an Annual General Meeting (AGM) where the participation is mandatory by all households or active members of the apartments. In the bylaw, the annual general meeting of the society shall be held on or before September 30 of each year, as provided under section 75(1) of the act; 2013 (Amendment) ${ }^{17)}$ (as there is no provision for extension to hold AGM). The key actions in AGM include reading the minutes of the last AGM, which reflect the recent report of the society's managerial actions, and auditing the financial management. Developers train the society members of SRS apartments on how to monitor the construction procedures periodically and how to handle the maintenance after allotment. The training also considers managing the buying and selling processes, commercial spaces, and parking space selling procedures, along with how the society should use the maintenance subsidy (SRA; 2018) ${ }^{20)}$ Society members instruct the dwellers about the necessary actions of some basic management and maintenance actions. Some societies also arrange training on participatory actions for AGM. For example, female members of the society train other female dwellers about the participatory activity in AGM. 


\section{3-4 Monitoring by the Authority}

Since this feature seems to be important, it needs to be present in the managerial actions in SRS apartments, so the question arises of whether the SRA monitors the maintenance services delivered by the housing societies of SRS apartments. There are two reasons to consider monitoring by the authority; first, regulation reference no-153(b) says, "It shall be the responsibility of the Committee to get audited accounts within four months from the closure of [the] financial year. At the same time, the society shall appoint the Statutory Auditor in its General Body Meeting from the panel of auditors approved by State Govt. The Statutory Auditor shall submit the Audit Report as provided in section 81 of the Act" (2013 Regulations). This means the authority should be informed about the financial maintenance of the SRS apartments by the society periodically. It can be said that SRS apartments have some financial, managerial actions that need regular auditing and without monitoring, possibilities of mismanagement might be predicted. Second, several articles focused on the supervision of management services because it has an official duty to abide by the codes of ethics and qualification requirements that serve to control how individual practitioners do their work (Kadushin, Alfred and Daniel; 2014). ${ }^{24)}$ Kadushin, Alfred, and Daniel claim in their book, Supervision in Social Work, that when some employees are performing a job, it should be a precise coordination of efforts by the group that efficiently accomplishes the objectives and that without monitoring them, it would be difficult to achieve success. Furthermore, according to the authority, all SRS apartments are ordered to proceed with mandatory construction and management regulations by the SRA, and that their societies should follow Maharashtra housing maintenance regulations. Therefore, this study has predicted that monitoring by the SRA should be included in the analytical frameworks of the research.

\section{Co-operative Housing Society (CHS) of Slum Rehabilitation Scheme (SRS) Apartments}

In 1961, the state government of Maharashtra developed "The Maharashtra Co-op Societies Act 1961" for all cooperative activity, including housing societies around the state. The Act has been amended twice to date and is followed by all housing societies including SRS apartments (Registrar cell; SRA) ${ }^{20)}$ within the peripheral boundary of Maharashtra. Recently, the SRA distributed a hand-out to all slum cooperative societies for the assembly as per the "97th Constitutional Amendment and Maharashtra Co-op Society (Amendment). ${ }^{17)}$ Ordinance 2013" for all housing societies. According to this regulation, the cooperative housing society should work as follows: "a society provides its members with open plots for housing, dwelling houses or flats; or if open plots, the dwelling houses or flats are already acquired, to provide its members common amenities and services." Following the rules, every SRS apartment has responsible officers such as a president, secretary, treasurer, and committee members who are elected by active members ${ }^{5}$ every five years.

\footnotetext{
5Active Member: Bylaw, a member shall be called as "Active Member" if (a) he/she has purchased and /or owns the flat (unit/room) under the slum cooperative society, (b) he/she has attended at least one general body meeting within a consecutive period of five years, and (c) he/she has at least paid the amount equivalent to three years of society maintenance service charges within the consecutive year of five years. Simultaneously, a member who is not active shall be a non-active member.
} 
Mumbai's SRS is executed in few steps with accordance regulations by the SRA. In the first step, slum dwellers need to form a cooperative society to proceed with SRS project constructions and distribute rooms/flats to the eligible dwellers ${ }^{6}$ after construction (SRA; 2018). ${ }^{20)}$ Society actions are usually executed through some of the leaders - such as the president, secretary, and committee members - who handle responsibilities including hiring a developer and an architect as per the necessity (SRA; 2018). ${ }^{20)}$ An accountable leader or promoter of the society serves as the representative of the slum coop society and executes other official formalities for SRS project applications at the registrar office in the SRA. This means the slum society is the principal responsible authority to execute SRS projects. Therefore, researchers claim the active participation of the local community can be perceived as the essential requirement for completed and successful SRS projects (Nijman; 2008, Jagdale; 2015). ${ }^{1), 7)}$ The society's first duty to maintain the financial management such as dweller's monthly maintenance charge, their long-term maintenance cost, and so on was discussed earlier. Cooperative societies of the SRS should be arranged regular society meetings and AGM with active members to manage the maintenance services of SRS apartments. Finally, all the managerial actions need to be checked by the authority who were ordered to follow these managerial actions.

\section{4-1 Characteristics of Three Interviewed Cooperative Housing Societies of SRS Apartments}

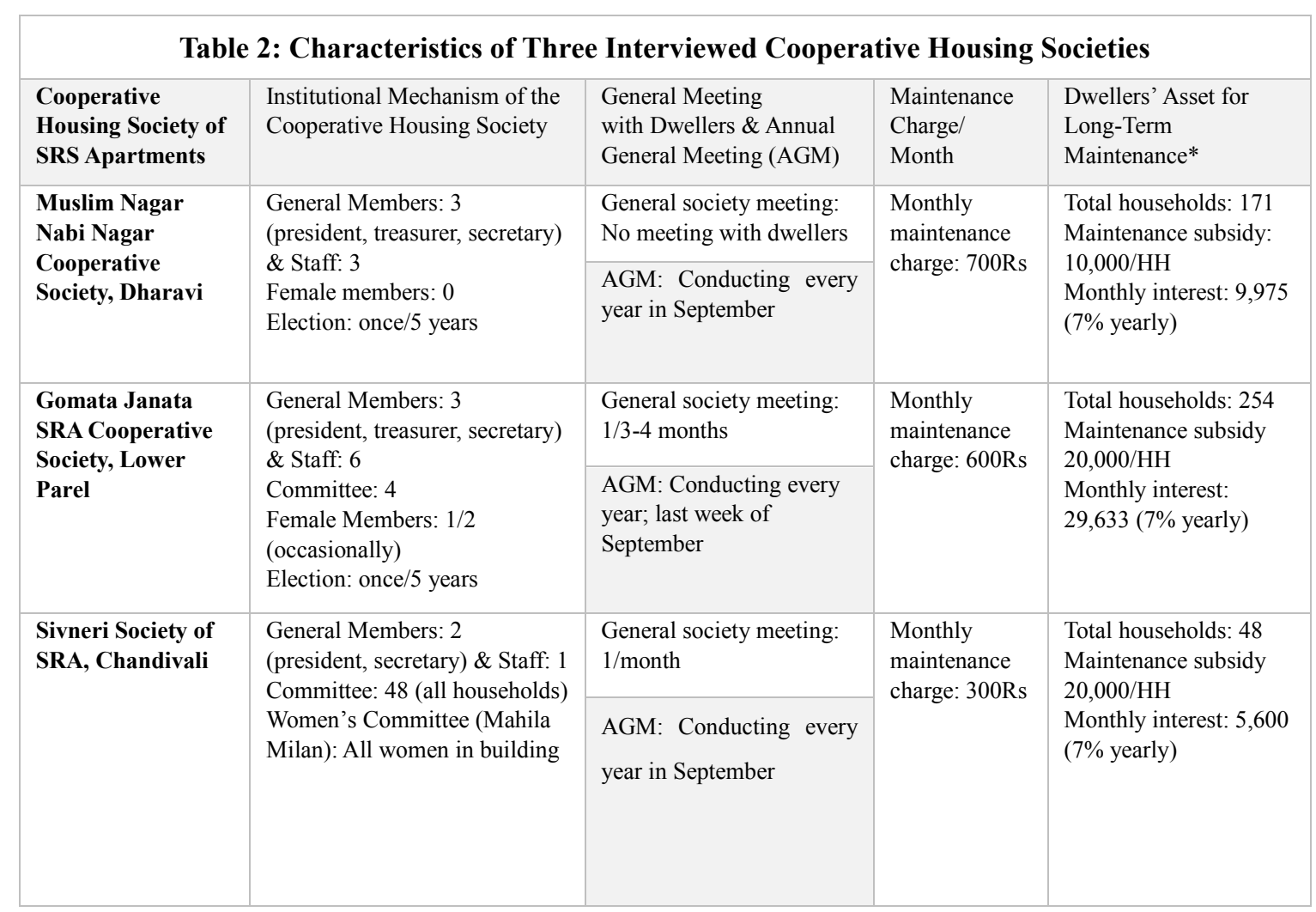

*Note: According to the regulation by SRA, developer should pay 20,000 rupees/each household (earlier 10,000 rupees) as a maintenance subsidy to avoid mismanagement due to lack of finance and for long-term maintenance service.

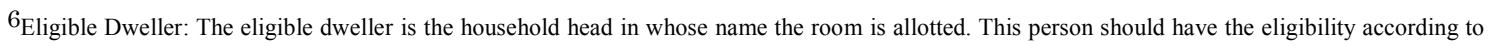
the Slum Rehabilitation Authority's criteria. It means he/she should have beena resident in the slum before the construction of SRS apartments. 
The interviews were conducted with the society's secretaries, as they contribute most to the building maintenance services in the SRS apartments. Table- 2 represents general characteristics and the recent conditions of the cooperative housing societies in the three SRS projects located in Dharavi, Lower Parel, and Chandivali. Most parts of the study have been based on whole interviews with the secretaries, which took place during several visits in January and February 2018 as case studies for SRS projects and the SRA. The project located in Dharavi has five apartments. Muslim Nagar Nabi Nagar Cooperative Housing Society works for this SRS project. The society's working duration is much longer, and the society is considerably older in comparison with the other societies interviewed in the research. The current secretary, Mr. Jarif Khan, has been selected in his society's general election which is usually held once every five years. Three permanent staffs are working on building maintenance such as cleaning, electric, and water supply management and door-to-door garbage collection. The society members secured dwellers' assets in the bank for long-term managerial services. Long-term management considered for future maintenance services include an elevator or generator replacement or any expensive maintenance service for the building. The interest of the assets is spent for the common area's electric bill, the water bill for whole building, and the building's taxation. The society does not arrange the monthly general body meeting; however, the AGM has been arranged every year in September. The society arranges 11 committee-member meetings during emergency requirements of the dwellers.

Gomata Janata SRA Cooperative Housing Society works for the SRS projects located at Lower Parel. The current secretary is Mr. Elsnath Gangaram Chavan, who was elected by dwellers in a vote that takes place every five years. According to the rule, active members (the owner/ household head) are allowed to cast their vote to nominate members for president, secretary, and treasurer. The society has one or two female members, and these members only attend the AGM. Since the female members participate on a temporary basis, they are not chosen through an election. The society has four committee members and six maintenance staffs. This society also maintains dwellers' assets using the same process as the Muslim Nagar Nabi Nagar cooperative society. They arrange a general body meeting with all active members once every three to four months; however, they also arrange meetings with the four committee members when an emergency arises. The AGM is also conducted as per regulation. The third interviewed society is the Sivneri Society of SRA, whose current secretary is Mr. Laxman Gorbore. He has been nominated in an election that takes place once every three years. The society was formed by an NGO named Nivara Hakk. The society has only paid staff for maintenance services. Other than the apartment society, a women's committee also works for management in this apartment. All adult women dwellers in the apartment are members of the committee, which was formed by an NGO known as Mahila Milan. These women contribute to the society by improving management in the building. The society arranges general body meetings every amonth and arranges an AGM every year in September. The financial management follows the same procedures as the other two case study cooperative societies. 


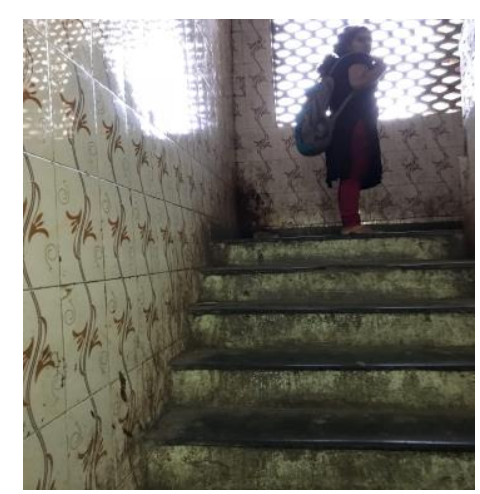

Picture 1: Staircase of the SRS apartment under Muslim Nagar Nabi Nagar Cooperative Housing Society at Dharavi, Mumbai

Source: Author (Taken during survey)

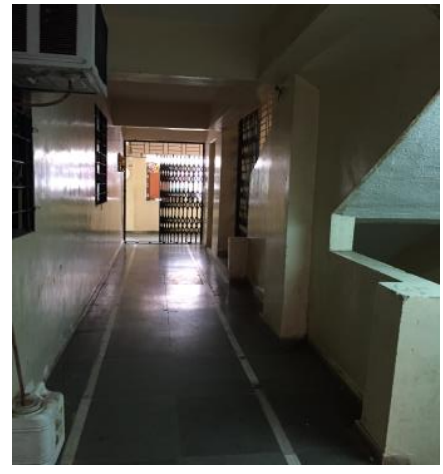

Picture 2: Corridor of the SRS apartment under Gomata Janata SRA Cooperative Society at Lower Parel, Mumbai

Source: Author (Taken during survey)

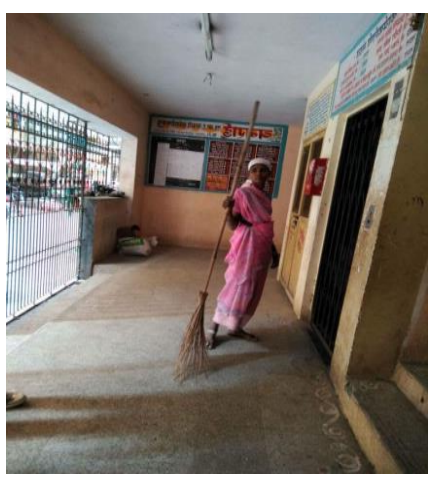

Picture 3: Staff is cleaning the corridor of the SRS apartment under Sivneri Society of SRA at Chandivali, Mumbai

Source: Author (Taken during survey)

\section{Recent Scenarios of the Three Case Studies of Cooperative Housing Societies of SRS Apartments}

The current situation of the cooperative housing societies of the three casestudies of SRS apartments are discussed in the three analytical frameworks below.

\section{5-1 Muslim Nagar Nabi Nagar Cooperative Housing Society}

Figure 2 has been developed according to the responses of the secretary of the Muslim Nagar Nabi Nagar Cooperative Society. The figure represents an analytical framework of the recent scenario of the society where four features are shown. Three features are presented as per the secretary's information such as (1) Financial Management, (2) Institutional Mechanism, and (3) Society General Meeting with Members. Since the research also intended to find the action of the feature (4) Monitoring by the Authority, the framework also contains it; however, the cooperative society is not monitored or audited by the Slum Rehabilitation Authority (SRA) or other organizations.

In this society, the feature "Financial Management" considers two indicators; (1) maintaining dwellers' asset and (2) management fee/month. The feature "Institutional Mechanism" combined with (1) general members and (2) staff's actions for maintenance services. The third feature of this society is "General Meeting with Dwellers" where two indicators (1) regular society meeting and (2) Annual General Meeting (AGM) contribute to the society's maintenance services. According to the secretary, dwellers' assets are reserved in the bank, and the monthly interest is spent on the billing for the common areas, and the building's taxation. However, some dwellers fail to pay the monthly maintenance charge. Therefore, the feature "Financial Management" does not properly contribute to better maintenance service. The society has an impressive number of committee members and other supportive members according to the secretary's response. However, the staff such as the cleaners, sweepers, or guards do not regular in their work, so the feature "Institutional Mechanism" does not properly support better maintenance in this apartment. Another feature, "Society General Meeting with the Dwellers", does not affect the improvement of management of this apartment. Due to the fact that the society only calls a meeting with the 11 
committee members when an emergency decision is needed, the society does not call a meeting with dwellers regularly. It means that the feature "Society General Meeting with Dwellers" does not contribute for sound management and maintenance services in this SRS project. The secretary mentions the AGM has been conducted in September every year as per the regulation.

Figure 2: Recent Condition of Muslim Nagar Nabi-Nagar Cooperative Society, SRS Apartment at Dharavi, Mumbai

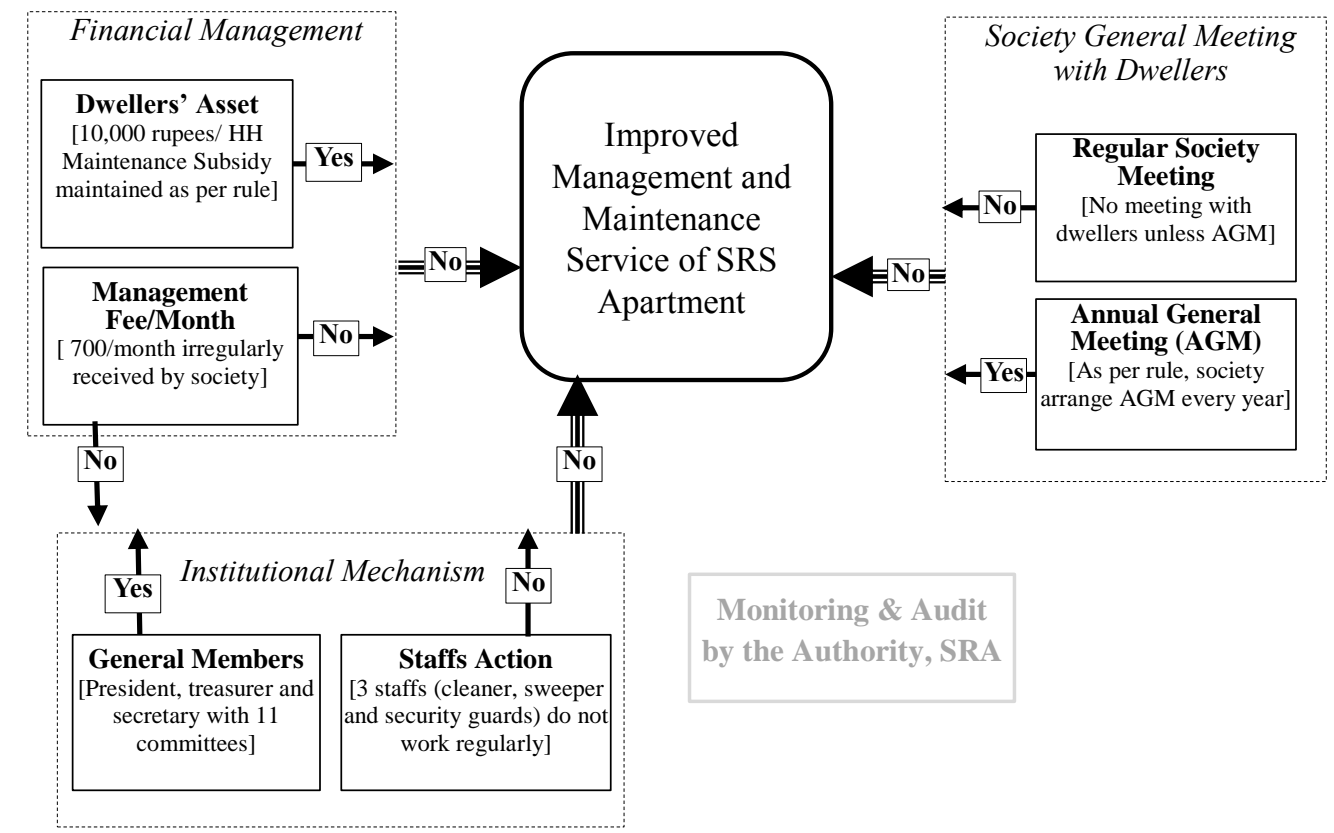

Figure 2: Recent Condition of Muslim Nagar Nabi-Nagar Cooperative Society, SRS Apartment at Dharavi, Mumbai

\section{5-2 Gomata Janata SRA Cooperative-Society}

Figure 3 has been developed according to the secretary's replies and several visits and observations in the apartments under Gomata Janata SRA Cooperative Society. The society currently follows all the mandatory features recommended by the SRA. "Financial Management" of the society has two indicators; (1) dwellers' asset maintenance and (2) maintenance fee/month. The monthly interest amount is used to pay common electrical and water supply bills and the building's taxation. The Gomata Janata cooperative society maintains the dwellers' assets as per the regulation, and they expend the interest amount for all billing and building taxation. They also receive a monthly management fee regularly from the dwellers. It means, "Financial Management" of Gomata Janata society properly contributes to improving management services. Another feature, "Society General Meeting with Dwellers" also helps with maintenance progress because of the two indicators (1) regular society meeting and (2) AGM are handling as per the regulation. Three indicators are shown in the feature "Institutional Mechanism"; (1) general members, (2) staff's actions and (3) female members. 
Figure 3: Recent Condition of Gomata Janata SRA Cooperative Society, SRS Apartment at Lower Parel, Mumbai

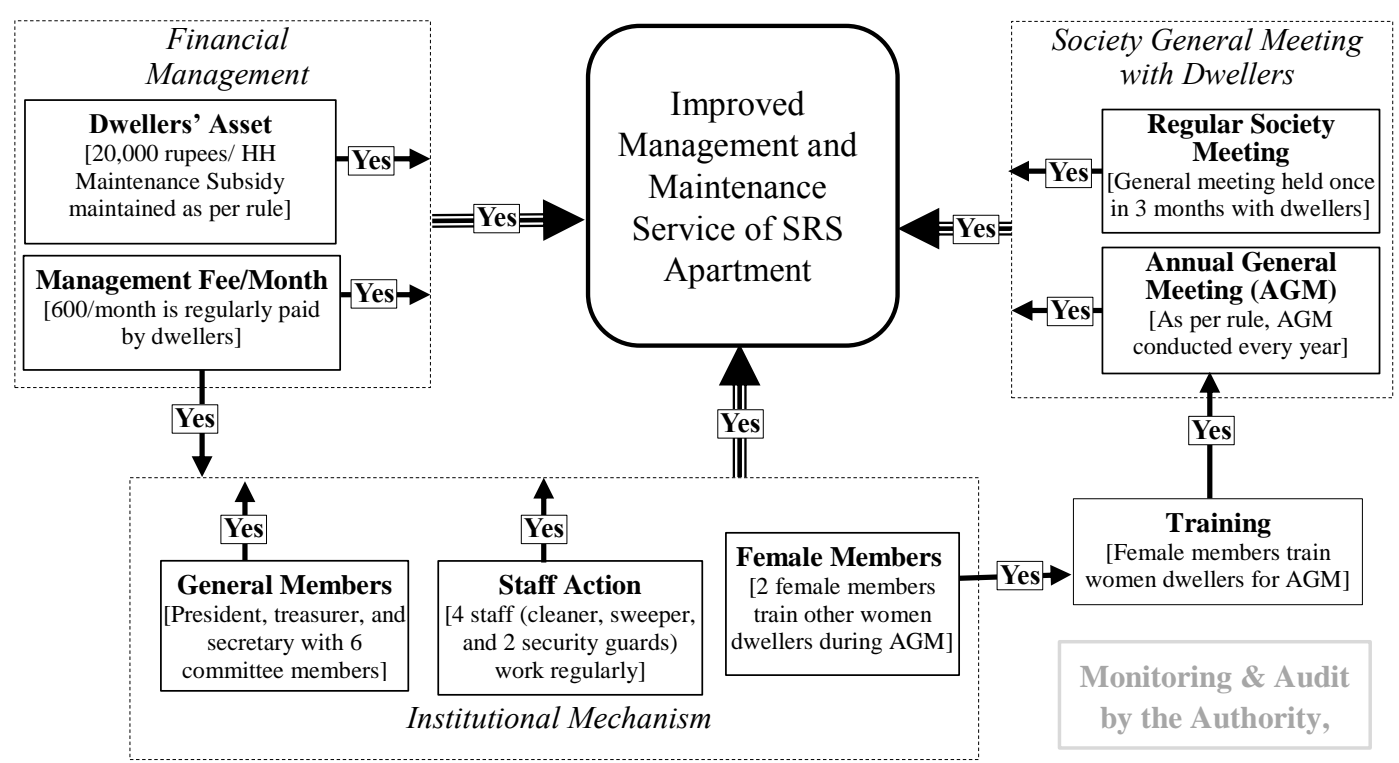

Figure 3: Recent Condition of Gomata Janata SRA Cooperative Society, SRS Apartment at Lower Parel, Mumbai

The inclusion of female members in the institutional body is mandatory according to the law, so women can participate in decisions for improving the overall managerial system. However, female activists in the society do not regularly participate in activities and only train women dwellers of the apartment during the AGM. Other than this specific action, no action is taken by the female members; therefore, there is no direct contribution for improving management services. The society has three general members: a president, treasurer and secretary, and four committee members. Among the three case studies of cooperative societies, Gomata Janata society has the highest number of staff for maintenance services. Thus, the feature "Institutional Mechanism," contributes to improved management and maintenance services of the apartment.

\section{5-3 Sivneri Society of SRA}

The SRS project at Chandivali contains 112 apartments, and every allotted apartment follows the same principles of managerial services. In this project, all SRS apartments have a building society that is supervised by an NGO. The NGO has been started to guide and monitor the societies of the Chandivali SRS project before the project construction.

Figure 4 has been developed by the responses by the secretary of Sivneri society and the members of the women's committee. The two indicators of "Financial Management," (1) dwellers' asset maintenance and (2) maintenance fee/month, is executed appropriately, as the society pays the bill and building tax on time. Furthermore, the dwellers pay the monthly charge without any delinquencies. This means, "Financial Management" contributes to better management. Then the factor, "Institutional Mechanism" has two indicators: (1) general members and (2) staff's actions. 
Figure 4: Recent Condition of Sivneri Society of SRA, SRS Apartment at Chandivali, Mumbai

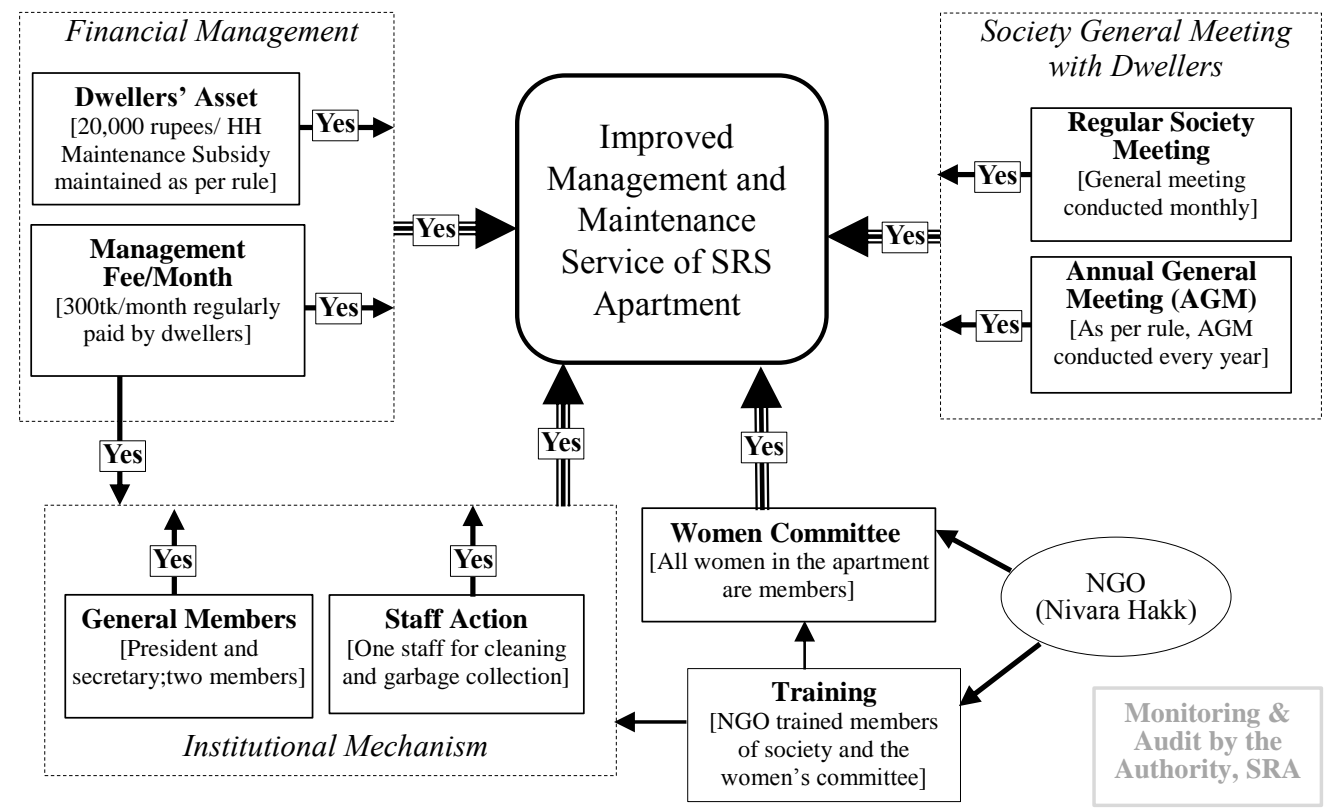

Figure 4: Recent Condition of Sivneri Society of SRA, SRS

Apartment at Chandivali, Mumbai

The society has an elected president and secretary as general members. The society has a maintenance staff, and she is regular. So, the "Institutional Mechanism" contributes to better management services in this apartment. There are two indicators: (1) regular society meeting arranged every month by the society, and (2) AGM is also conducted regularly. The factor, "Society General Meeting with Dwellers", also contributes to better management as its indicators perform as per the regulatory requirement.

The study found cooperative societies in Chandivali SRS projects contain another factor: the "Women's Committee" operates exclusively for managerial services. Including the Sivneri society, all societies in the project provide women community, called "Mahila Milan", and work independently for better maintenance service and financial up-gradation in their building. The NGO "Nivara Hakk" formed and trained the women's committee and trained the cooperative society members on processes to increases the quality of managerial services.

\section{The Mechanism to Improve Managerial Service of SRS Apartments}

According to the interviews with society secretaries, observations, and consideration for regulations, the features for better managerial services of SRS apartments are discussed below.

\section{6-1 Financial Management}

The Financial Management of the three interviewed societies properly manage "Dwellers' Assets"; therefore, the dwellers under these societies do not face electric and water supply disturbance and harassment. So, the indicator "Dwellers' Assets" contributes to better managerial 
services ([1]in Figure 5). The financial mismanagement of the old SRS apartments has been noticed during the interview with the secretaries. For example, Muslim Nagar Nabi Nagar cooperative society works for an old SRS project and the research found some financial mismanagement. Dwellers under the society received 10,000 Rs/household as a maintenance subsidy from the builder, which is much lower than the recent subsidy. The amount is insufficient to pay the common area electric bill, water bill, building tax, and the salaries of maintenance staff. So, the society claimed a high maintenance charge, which was expensive for SRS dwellers and majority of them failed to pay. Due to financial mismanagement, the society pay the staff's salary irregularly; this results staffs are irregular to the maintenance services. The other two case study societies of the study, are receiving the monthly maintenance fee regularly. So, the staff work regularly and receive their salaries regularly. Thus, "Maintenance fee/month"([2] in Figure 5) needs to be paid by SRS apartment dwellers in time for better management services. The study found that the monthly maintenance charge ([3] in Figure 5) is essential to execute some tasks of the institutional body of cooperative societies in the study's targeted SRS apartments.

\section{6-2 Institutional Mechanism}

The cooperative societies of SRS apartments have members and staff according to the regulatory recommendation in Maharashtra Housing Regulation 2013. The number of "General Members of the Societies" is fixed in the regulation and the research found the case study cooperative societies have the general members as per guideline ([5] in Figure 5). Societies of SRS apartment should have the required number of staff ([4] in Figure 5) to produce quality managerial services as well. The members and staff are the key drivers to run a successful cooperative society for managerial services in the case study SRS apartments observed.

\section{6-3 Women's Committee}

The research found that the "Women's Committee" contributes to improving management and maintenance services in SRS apartments ([6] in Figure 5). The inclusion of female members in the cooperative society is mandatory in regulations. Therefore, societies in SRS apartments can introduce women's groups as a women's committee for improved maintenance services. The research found in the Chandivali SRS project, women dwellers play a vital role to improve managerial services. Cooperative societies involved female dwellers as women committee members who worked for maintenance services. Every week, all the ladies of the apartment have a meeting, and they discuss ways to improve the current management of their building and ways to improve their financial capacity. This frequent meeting increases communication and improves the overall managerial system. The leader of the women's committee expresses her ideas to improve managerial service in the monthly meeting with society members and other dwellers. The leader's idea for better maintenance gets priority in consideration by the society members as the committee arranging the meeting gather more frequently than society general meetings. It shows that involving women dwellers as decision makers for improving overall management and maintenance in the study's targeted SRS apartments is effective. Meanwhile, cooperative society at the Lower Parel SRS project involved women in specialized training ([7] and [8] in Figure 5) before the Annual General Meeting (AGM). So, the women's committee not only contributes to 
improved managerial services, but also the members can train for meetings and other administrative processes in the case study cooperative societies.

\section{6-4 Society General Meeting with Dwellers}

According to the regulation, all the interviewed societies of SRS apartments arrange an AGM every year September in order to improving overall managerial services and disclose financial auditing to the dwellers ([9] in Figure 5). Furthermore, the study reveals the dwellers also have a chance to judge the managerial services in the annual general meeting. During the interview, the study observed a distinct gap between the dwellers and the managerial body in the Muslim Nagar Nabi Nagar Cooperative Society. The society does not arrange the general meeting with dwellers, whereas a general meeting needs to be arranged at least once every three months as per the regulations. As stated before, the society was involved in some financial mismanagement, whereas the issue could have been resolved if the society and dwellers had a discussion about the problem in a regular general meeting. Thus, to increase the communication level and to resolve the financial mismanagement, a monthly or quarterly general meeting with society members and dwellers is recommended ([10] and [11] in Figure 5).

Figure 5: Mechanism to Improving Managerial Services in SRS Apartments

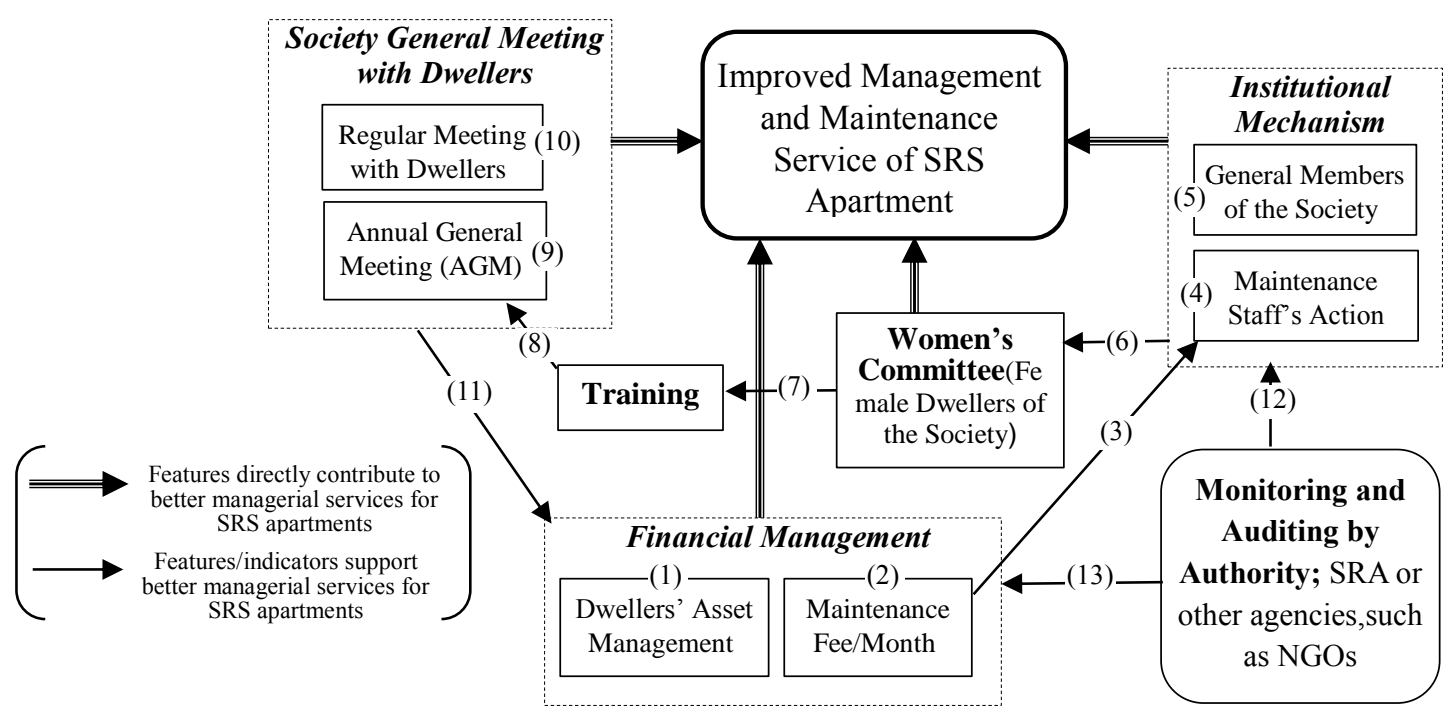

Figure 5: Mechanism to Improving Managerial Services in SRS Apartments

\section{6-5 Monitoring and Auditing}

Monitoring and auditing are one of the effective features to improve the managerial services in SRS apartments. Slum Rehabilitation Authority need to monitor the managerial activity and audit the financial management to execute proper maintenance service on time. The interviewed society of the Dharavi SRS projects does not consider some mandatory regulatory managerial actions. Since the authority does not monitor the maintenance action, the society, as well as the dwellers, easily disobey mandatory regulations. Moreover, without monitoring by the SRA, there is no 
emphasis on the necessity to improve the conditions of old SRS apartments. The monitoring by the authority can change the current scenario, as it would increase the enthusiasm to follow the regulation by both society members and dwellers. Slum Rehabilitation Authority can also involve NGOs or other social welfare agencies to monitor or supervise the managerial activity of SRS apartments as an alternative. The research found that in the Chandivali SRS projects, there is no monitoring by SRA, but an NGO supervises the cooperative societies regularly. In the project, there is a small local office of the NGO which is governed by some members of the slum dwellers and from that office they monitor the societies from time to time. For this reason, the management of SRS apartments in the projects is good, and dwellers are satisfied with its maintenance service - much more than the other two case-study cooperative societies. Thus, monitoring by SRA or other agencies like NGOs ([12] in Figure 5) needs to be recommended and considered by the institutional bodies of SRS apartments. Meanwhile, yearly auditing is done by the society during the AGM, but the auditing by societies usually is not supervised by the SRA or any agencies. As the auditing also done by the society's members, the study found some financial mismanagement in the old SRS apartment in Dharavi, even after arranging a regular AGM. Thus, there would be some possibilities, including the feature of supervision ([13] in figure 5) of the financial management by the authority; any alternative agencies such as NGO is also suggested.

\section{6-6 Discussion}

Dharavi has many slums and contains Asia's largest slum (Nijman; 2008, Jagdale; 2014); 1),7) naturally, all the SRS projects at Dharavi are surrounded by slums. Dwellers of the SRS apartments believe that they live in better conditions than others in their neighborhood. So, they do not feel the necessity to change their overall maintenance service. Here, the surrounding environment does not support SRS dwellers' interest to improve the maintenance service. Furthermore, the cooperative society of the SRS project at Dharavi does not consider some rules such as arranging general society meetings, including female dwellers in the institutional body, and so on. At the same time, dwellers are also dishonest about their monthly maintenance payment. Thus, society members are unable to pay the salary to the management staff such as the cleaners, guards, etc. The study has illuminated that the monitoring by the authority (SRA) could change the current scenario, as it would increase the willingness to follow regulations by both society members and dwellers of these SRS apartments. The authority realized the maintenance subsidy or dwellers' assets needed to be raised and amended the rule. After the revision, the developers increased the subsidy amount. However, the study revealed that the authority neglected to provide some technical or regulatory measures inwhich the old SRS apartments could improve the maintenance services without raising the monthly charge. Meanwhile in India, women's empowerment refers to increases in the spiritual, political, social, educational, gender, or economic strength of individuals and communities - as is argued by some researchers (Wieringa S.; 1994, Moser; 2012). ${ }^{25), 26)}$ Therefore, the women's group also could contribute some new actions of managerial services in old SRS apartments. If the society of old SRS apartments would create a women's committee, then it could support many managerial actions that would help to improve the maintenance services - more so than the current condition. Moreover, the women's committee works for their apartment, and they do not seek payment. Through their support, 
cooperative societies might handle maintenance services without raising the monthly fee for dwellers.

The Gomata Janata SRA cooperative society at the Lower Parel SRS apartments follows the regulations recommended in the rulebook distributed by the authority (SRA). However, the number of management staff and the monthly maintenance charge by dwellers are relatively high even though the households received the revised maintenance subsidy. Notably, during observations, the study found that the area is surrounded by upscale neighborhoods, so dwellers of this project are influenced by wanting to live like the rich. Even though the society is not monitored and audited by the SRA or any other agency, the dwellers are much aware of their building maintenance. They are quite serious about the maintenance and their building's beautification, similar to their wealthy neighbors. Here, the dwellers are worried whether they need to leave the area due to less maintenance both on the outside and inside of the building and will get criticisms from their neighbors. Therefore, they follow the announced instructions from the society's office.

Meanwhile, the Chandivali SRS project dwellers are also satisfied with their maintenance service without neighborhood influence like the SRS project case studies located at Lower Parel or Dharavi. The research revealed that the involvement of women in managerial actions in SRS apartments reduces mismanagement in services and financial contributions from the dwellers. Further, it is beneficial to have a supervision wing created by an NGO which regularly monitors the society. The project is located slightly far from the central city; therefore, the dwellers travel long distances to their workplace. Naturally, the travel time and cost make the dwellers unsatisfied to stay in this project, but they are satisfied with living in the apartment. The study already has discussed that SRS apartment dwellers' living satisfaction is related to the building maintenance services (Alam, Matsuyuki; 2017). ${ }^{16)}$ Chandivali SRS apartment dwellers also demonstrate a high appreciation for maintenance services in their building. It could be said that the potential activity of women's group in maintenance services and regular monitoring motivated the society to operate a standard management service.

\section{Recommendations and Conclusion}

The present article intended to identify the necessary actions that would improve the management and maintenance services of SRS apartments. This study contributes to the literature because it shows that quality managerial services increase dwellers' living satisfaction. Some research suggested identifying the essential variables, and the physical approach would be the tools to improve housing management. At the same time, the analytical framework with essential variables could also advance the current condition of housing managerial actions. For this reason, the study involved interviews the key person of the three cooperative housing societies located in three areas of Mumbai and the findings were evaluated with three analytical frameworks. Finally, the study proposes a possible mechanism that may improve the overall managerial actions in the SRS apartments case studies in this research.

The research found in the interviews that old SRS apartments faced financial mismanagement due to a low maintenance subsidy. Moreover, no action has been taken to improve the managerial action there. It also observed that the three cooperative societies where interviews were conducted 
with their secretaries are not monitored by the SRA. If the SRA or any other organization monitors and instructs both society members and dwellers to follow the regulation, that could improve the managerial actions by the society. Since the dwellers interviewed from the SRS apartment at Dharavi failed to pay the regular maintenance fee, an irregularity in the payment of maintenance staff salaries emerges. So, like the women's involvement in the management services at the Chandivali SRS apartments, women dwellers of the Dharavi SRS apartments could contribute to improving the management services. Their contributions would be reduced to the monthly management charge. Undoubtedly, the SRS apartment dwellers under the Gomata Janata cooperative society of SRA are satisfied with their maintenance service; how they are influenced by their surrounding neighborhoods could be considered as an exceptional case. All SRS apartments in Mumbai will not get the same environmental encouragement as the case study SRS apartments at Lower Parel. In the Gomata Janata SRA cooperative society, female members only train other women dwellers during the AGM. However, female members can also support maintenance service, which might reduce the monthly maintenance cost.

The most effective management procedure depends on the active participation of the community; otherwise, the service will fail due to lack of knowledge. This means that the community plays a vital role in handling SRS projects and their knowledge about the maintenance services is essential to execute a successful SRS project. The role of NGOs in SRS projects has already been discussed in several papers; the research recommends harnessing their intermediary contribution for increasing the new, uncontrolled circumstances in old SRS apartments. The authority can engage NGOs or other social organizations for supervising or monitoring the managerial actions if they fail. Non-profits or other social welfare organizations could act as a bridge between the slum community and authority to improve dwellers' overall satisfaction with living in SRS apartments.

\section{Acknowledgement}

The authors like to thank the reviewers for their valuable comments on the paper that improve the quality. Simultaneously, the authors like to acknowledge the secretary of Muslim Nagar Nabi Nagar Cooperative Housing Society at Dharavi, the secretary of Gomata Janata SRA Cooperative Society and, the secretary of Sivneri Society of SRA for their information about the recent managerial services of their society. We would also like to acknowledge the officers of the Slum Rehabilitation Authority (SRA) at Mumbai for the information and regulatory knowledge about the housing managerial services of SRS apartments. Lastly, we would like to acknowledge the dwellers of SRS apartments, who gave us their valuable time for the questionnaire survey. 


\section{References}

1. Agbola, T, NGOs, and community development in urban areas: A Nigerian case study, Cities.1994. Vol 11(1). Pg59-67, Eng.

2. ALAM, Sayeda Saika Binte, and Mihoko MATSUYUKI. "Dwellers Satisfaction on Slum Rehabilitation Scheme; SRS and its Affecting Factors in Mumbai, India." Urban and Regional Planning Review. 2018. Vol-5. Pg67-86. Eng.

3. Banerjee, Banashree. "Maximising the impact of tenure and infrastructure programmes on housing conditions: The case of slums in Indian cities." International Conference on Adequate and Affordable Housing for All: Research, Policy, Practice, Toronto, Canada. 2004. Eng.

4. Coase, Ronald H. "The problem of social cost." Classic papers in natural resource economics. Palgrave Macmillan, London. 1960. Pg87-137. Eng.

5. Davis, M. Planet of slums, New Perspectives Quarterly. 2006.Vol- 23(2). Pg6-11, Eng.

6. DAS, P. K. Slums: the continuing struggle for housing. Bombay and Mumbai: The city in transition. 2003. Pg207-234. Eng.

7. Geurts, J. L. A., and Joldersma, C. Methodology for participatory policy analysis, European Journal of Operational Research. 2001. Vol- 128 (2). Pg300-310. Eng.

8. Habitat UN. Slum Almanac 2015-2016: Tracking Improvement in the Lives of Slum Dwellers. Participatory Slum Upgrading Programme. 2016. Eng.

9. International Cooperative Alliance; https://www.ica.coop/en/history-alliance(Last visited; Dec; 2018)

10. Jagdale, Rohit H. "An overview of slum rehabilitation schemes in Mumbai, India." PhD diss. 2014. Eng.

11. Jan Nijman. Against the odds: Slum rehabilitation in neoliberal Mumbai. Elsevier Ltd. 2008. Vol. 25. Pg 73-85. Eng.

12. Kadushin, Alfred, and Daniel Harkness. Supervision in social work. Columbia University Press, 2014. Eng.

13. "Model Bye-Laws of Cooperative Housing Society", 97th Constitutional Amendment and Maharashtra Cooperative Societies (Amendment).April 2013,at 2:23 AM. Eng.

14. Management and Maintenance of Tenements: Final Detail Report, "Support to National Policies for Urban Poverty Reduction" (SNPUPR) for Strengthening National Resource Center (NRC) of India. June 2013. Eng.

15. Mukhija, Vinit. "Enabling slum redevelopment in Mumbai: Policy paradox in practice." Housing Studies 16. 2001. Vol- 6. Pg791-806. Eng.

16. Mahadevia, Darshini, Neha Bhatia, and Bharti Bhonsale. Slum rehabilitation schemes (SRS) across Ahmedabad: Role of an external agency. CUE Working Paper 27, Centre for Urban Equity, CEPT University, Ahmedabad. 2014. Eng.

17. Moser CO. Gender planning and development: Theory, practice and training. Routledge; 2012 Oct 12. Eng.

18. Nallathiga R. Regulatory impacts on land and housing markets in Mumbai. Nagarlok 
(Journal of Indian Institute of Public Administration). 2005 Sep 1. Vol-37(3). Pg 50-65. Eng.

19. Neuwirth, R. "Shadow Cities; A Billion Squatters". A New Urban World. Routledge. New York. 2004.Pg 25-67. Eng.

20. Restrepo, P. Moving in-selling out: The outcomes of slum rehabilitation in Mumbai. In International conference on applied economics-ICOAE. 2010. Pg 641-648. Eng.

21. Ronita Bardhan, Sayantani Sarkar, and Arnab Jana, Nagendra R. Velaga. "Mumbai slums since independence". Evaluating the policy outcomes. Habitat International. 2015. Vol- 50. Pg1-11. Eng.

22. Risbud, Neelima. "The case of Mumbai, India." Understanding slums: case study for the Global Report on Human Settlements. 2003. Eng.

23. Sukumar, G. Institutional potential of housing cooperatives for low-income households: The case of India. Habitat International. 2001. Vol- 25(2). Pg147-174. Eng.

24. Slum Rehabilitation Authority (SRA), Slum Rehabilitation Authority. http://www.sra.gov.in (Last accessed 2018-11-25).

25. Wieringa S. Women's interests and empowerment: gender planning reconsidered. Development and change. 1994. Vol- 25(4). Pg 829-48. Eng.

26. Zope PE, Eldho TI, Jothiprakash V. Impacts of urbanization on flooding of a coastal urban catchment: a case study of Mumbai City, India. Natural Hazards. 2015 Jan 1. Vol- 75(1). Pg887-908. Eng. 